\title{
ОСОБЛИВОСТІ ПЕРЕБІГУ ВЕГЕТАТИВНИХ ПОРУШЕНЬ У ХВОРИХ, ЯКІ ПЕРЕБУВАЮТЬ НА ПРОГРАМНОМУ ГЕМОДІАЛІЗІ, З УРАХУВАННЯМ НАЯВНОСТІ У НИХ ЦУКРОВОГО ДІАБЕТУ 2-ГО ТИПУ
}

\author{
Українська медична стоматологічна академія, Полтава
}

○С. Т. Рустамян, І. П. Катеренчук

РЕзюМЕ. Мета - провести порівняльний аналіз клінічних проявів вегетативних порушень у хворих, які перебувають на програмному гемодіалізі, з урахуванням наявності у них цукрового діабету 2-го типу.

Матеріал і методи. У дослідження залучено 93 хворих, які лікувались у 2019 р. у центрі нефрології та діалізу м. Полтава. Залежно від стадії хронічної хвороби нирок (ХХH) виокремлено дві групи хворих - 44 хворих (47,3 \%), що перебувають на програмному гемодіалізі (дослідна група - ДГ) та 49 хворих (52,7 \%) з ХХН I-ІІ стадій (контрольна група -КГ), у кожній з яких хворі були стратифіковані на дві підгрупи: з наявністю цукрового діабету 2-го типу (ЦД) та без ЦД: у ДГ 20 і 24 пацієнти, у КГ 26 і 23 пацієнти відповідно. Для виявлення ознак вегетативних порушень використовували опитувальник А. М. Вейна. Вегетативну дисфункцію діагностували коли сумарний бал перевищував 15. Статистичний аналіз проводили за допомогою програмного забезпечення Microsoft Excel, застосовуючи варіанти статистичного обчислення (середньоквадратичне відхилення, середнє арифметичне, стандартну похибку). Вірогідність відмінностей між порівняльними групами визначали за допомогою параметричного критерію Стьюдента.

Результати. У результаті анкетування пацієнтів за стандартизованим опитувальником А. М. Вейна встановлено, що у хворих, які перебувають на програмному гемодіалізі з ЦД у сукупності відповідей хворих ознаки вегетативних розладів оцінювалися $(46,1 \pm 9,1)$ балів при мінімально-максимальних значеннях $(19-58)$, тоді як у контрольній групі з ЦД $(11,4 \pm 3,1)$ балів, при мінімально-максимальних значеннях $(7-18)$, p<0,001. Таке саме значення отримано і при порівнянні ДГ без ЦД $(34,8 \pm 4,6)$ балів, при мінімально-максимальних значеннях (17-43) і КГ без ЦД $(9,4 \pm 2,5)$ балів, при мінімально-максимальних значеннях (7-15), p<0,001. Частота виникнення вегетативної дисфункції у пацієнтів ДГ з ЦД та ДГ без ЦД не мала статистично значимої різниці ( $<0,05)$, але сама вегетативна дисфункція у групах відрізнялася за структурою.

Висновки. Прояви вегетативної дисфункції у пацієнтів з хронічною хворобою нирок з цукровим діабетом 2-го типу відрізняються за структурою від проявів у хворих з хронічною хворобою нирок без цукрового діабету. Зі зростанням стадії хронічної хвороби нирок у пацієнтів з цукровим діабетом та без цукрового діабету відзначалося збільшення проявів вегетативної дисфункції, які не усуваються проведенням сеансів гемодіалізу.

КлючовІ СлОВА: гемодіаліз; ниркова недостатність; вегетативні розлади.

Вступ. Хронічна хвороба нирок (ХХH), особливо її термінальна стадія, $\epsilon$ соціальною та економічною проблемою не тільки в Україні, а й у всьому світі. Ця проблема набуває особливої актуальності з огляду на стабільне збільшення кількості хворих на вказану патологію. У дослідженні Global Burden of Disease (GBD) було підраховано, що у 2015 році від ниркової недостатності померло 1,2 мільйона людей, що на 32 \% більше, ніж у 2005 році $[1,2]$. У 2010 році, за їхніми підрахунками, 2,3-7,1 мільйона людей із термінальною стадією ниркової недостатності померли без доступу до хронічного діалізу [3]. Крім того, щорічно від гострого пошкодження нирок помирає близько 1,7 мільйона людей. Загалом приблизно 5-10 мільйонів людей щорічно помирають від захворювання нирок. Зважаючи на обмежені епідеміологічні дані, загальну недостатню обізнаність та часто поганий доступ до лабораторних послуг, такі цифри, ймовірно, недооцінені $[1,4]$. У 2010 році в усьому світі нирковозамісну терапію отримували 2,62 млн пацієнтів, і потреба в діалізі, за прогнозами, до 2030 року збільшиться вдвічі [3]. Однак, незважаючи на значний прогрес у технічному забезпеченні та розширенні можливостей більш адекватного заміщення втрачених функцій нирки, тобто не тільки гемодіалізу, а й перитонеального діалізу, трансплантації нирки, задоволеності результатами замісної терапії немає. Це пов'язано не тільки зі збереженим серйозним прогнозом і незадовільними показниками виживаності, а й із тим, що на сучасному етапі розвитку медицини все актуальнішою стає проблема "виживання" хворого і збереження людини як соціальної особистості, поліпшення якості її життя як міра оцінки успішності лікувальних заходів, вивчення психоемоційного стану хворих, що в сукупності впливають на перебіг основного захворювання та на функціонування вегетативної нервової системи, призводячи то різноманітних вегетатативних порушень $[5,6]$.

За визначенням А. М. Вейна, вегетативна дисфункція (ВД) - це порушення функції вегетативної нервової системи організму, зумовлене розладами нейрогенної регуляції. Одними із численних етіологічних факторів виникнення ВД $\epsilon$ гормональний дисбаланс, хронічні захворювання, тривале психо- 
Огляди літератури, оригінальні дослідження, погляд на проблему, випадок з практики, короткі повідомлення емоційне перенапруження, що часто спостерігається у хворих, які перебувають на нирковозамісній терапії (НЗТ). Вегетативна нервова система (ВНС) бере активну участь у процесах адаптації та патогенезі більшості соматичних захворювань, у тому числі й при XXН, тому оцінка її стану відіграє важливу роль у комплексній терапії хронічних ниркових хвороб [7]. Вивчення та аналіз клінічних проявів вегетативних розладів у хворих із хронічною хворобою нирок, що перебувають на програмному гемодіалізі, допоможе лікарям загальної практики, терапевтам і нефрологам детальніше зрозуміти симптоматику захворювання діалізних хворих та правильно провести медикаментозну корекцію вегетативної дисфункції [8].

Зв'язок публікації з плановими науково-дослідними роботами. Стаття підготовлена згідно з планом науково-дослідної роботи кафедри внутрішньої медицини № 2 з професійними хворобами Української медичної стоматологічної академії (м. Полтава) «Дослідження оцінки поєднаного впливу факторів кардіоваскулярного ризику на коморбідний перебіг артеріальної гіпертензії, ішемічної хвороби серця і хронічної хвороби нирок, особливості профілактики та реабілітації». Держреєстрація № 0119 U102851.

Мета - провести порівняльний аналіз клінічних проявів вегетативних порушень у хворих, які перебувають на програмному гемодіалізі, з урахуванням наявності у них цукрового діабету 2-го типу.

Матеріал і методи дослідження. У дослідження залучено 93 хворих, які лікувались у 2019 р. у центрі нефрології та діалізу комунального підприємства «Полтавська обласна клінічна лікарня імені М. В. Скліфосовського Полтавської обласної ради». Залежно від стадії захворювання XXН виокремлено дві групи хворих - 44 хворих (47,3 \%), що перебувають на програмному гемодіалізі (дослідна група - Дг) та 49 хворих (52,7 \%) з XXH I-ІІ стадій (контрольна група - КГ), у кожній з яких хворі були стратифіковані на дві підгрупи: 3 наявністю цукрового діабету 2-го типу (ЦД) та без нього: ДГ 20 і 24 пацієнти, КГ 26 і 23 пацієнти відповідно. За гендерними ознаками всі пацієнти розподілилися так: 62 (66,7 \%) жінки та 31 (33,3 \%) чоловік. У дослідну групу увійшли 24 (25,8 \%) жінки та 20 (21,5\%) чоловіків, в контрольну - 38 (40,9\%) жінок та 11 (11,8 \%) чоловіків.

Для виявлення ознак вегетативних порушень використовували опитувальник А. М. Вейна [8]. Вегетативну дисфункцію діагностували у тих випадках, коли сумарний бал перевищував 15.

Статистичний аналіз проводили за допомогою програмного забезпечення Microsoft Excel, застосовуючи варіанти статистичного обчислен-

ня (середньоквадратичне відхилення, середнє арифметичне, стандартну похибку). Вірогідність відмінностей між порівнюваними групами визначали за допомогою параметричного критерію Стьюдента.

Результати й обговорення. Результати досліджень засвідчили, що всі пацієнти Дг з ЦД мали вегетативні порушення, з максимальними показниками кардіоваскулярного синдрому (відчуття серцебиття, перебої у роботі серця, відчуття «завмирання» серця у 19 (95,0 \%) пацієнтів), цереброваскулярного синдрому (головний біль - у 20 пацієнтів (100,0 \%), випадки втрати свідомості - у 3 (15,0 \%) пацієнтів). Також виявляли такі ознаки як зниження працездатності, швидку втомлюваність, що проявлялися у 100,0 \% пацієнтів ДГ з ЦД. У групі порівняння, тобто в ДГ без ЦД, ознаки кардіоваскулярного синдрому діагностували у 21 (87,5%) пацієнта, головний біль - у 22 (91,6 \%) пацієнтів. Зниження працездатності, швидку втомлюваність виявили у 20 (83,3 \%) пацієнтів. Натомість у КГ з ЦД кардіоваскулярний синдром спостерігався лише в 12 пацієнтів (46,0 \%), цереброваскулярний - у 11 пацієнтів (42,3 \%) відповідно (табл. 1).

Порушення сну $є$ однією із складових дезадаптаційних процесів, які викликані тривогою та/ чи депресією і мають спільні соматовегетативні ознаки. До них також належать неспецифічні скарги з боку серцево-судинної системи (відчуття перебоїв у роботі серця, загруднинний біль, тахікардія чи брадикардія), швидка втомлюваність, зниження працездатності, що було виявлено максимально у хворих ДГ з ЦД - у 15 (75,0 \%) пацієнтів, тоді як в КГ з ЦД лише у 2 (8,6 \%) пацієнтів.

За результатами анкетування пацієнтів за стандартизованим опитувальником А. М. Вейна встановлено, що у хворих із ЦД, які перебувають на програмному гемодіалізі, ознаки вегетативних розладів оцінювалися у $(46,1 \pm 9,1)$ балів при мінімально-максимальних значеннях (19-58), тоді як у контрольній групі з ЦД $(11,4 \pm 3,1)$ балів, при мінімально-максимальних значеннях (7-18), р<0,001. Аналогічні показники отримано і при порівнянні Дг без ЦД- $(34,8 \pm 4,6)$ балів, при мінімально-максимальних значеннях (17-43) і КГ без ЦД $(9,4 \pm 2,5)$ балів, при мінімально-максимальних значеннях (715), p<0,001. Частота виникнення вегетативної дисфункції у ДГ з ЦД та ДГ без ЦД не мала статистично значимої різниці ( $>0,05)$, але сама вегетативна дисфункція у групах відрізнялася за структурою. у ДГ з ЦД частіше виникав синдром периферійних судинних порушень - схильність до почервоніння/ блідість обличчя (40,0 \% та 37,5 \% відповідно), оніміння/похолодіння пальців (45,0 \% та 29,1 \% відповідно), зміна забарвлення шкіри рук, стоп (80,0 \% та 45,8 \% відповідно). 
Огляди літератури, оригінальні дослідження, погляд на проблему, випадок з практики, короткі повідомлення

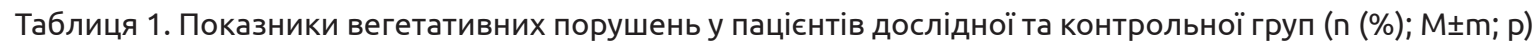

\begin{tabular}{|c|c|c|c|c|}
\hline Показники & $\begin{array}{l}\text { ДГ з ЦД } \\
(\text { Дг 1), } \\
\text { п; \% }\end{array}$ & $\begin{array}{l}\text { КГ з ЦД } \\
(\text { КГ 1), } \\
\text { п; \% }\end{array}$ & $\begin{array}{l}\text { дг без ЦД } \\
\text { (ДГ 2), } \\
\text { п; \% }\end{array}$ & $\begin{array}{l}\text { КГ без ЦД } \\
\text { (КГ 2), } \\
\text { п; \% }\end{array}$ \\
\hline $\begin{array}{l}\text { Схильність до почервоніння чи блідості } \\
\text { обличчя при будь-якому хвилюванні }\end{array}$ & $8(40,0)$ & $3(11,5)$ & $9(37,5)$ & $2(8,7)$ \\
\hline $\begin{array}{l}\text { Оніміння чи похолодання пальців стоп, кистей, } \\
\text { чи цілком }\end{array}$ & $9(45,0)$ & $6(23,0)$ & $7(29,1)$ & $2(8,7)$ \\
\hline $\begin{array}{l}\text { Зміна забарвлення шкіри пальців кистей, стоп, } \\
\text { чи цілком }\end{array}$ & $16(80,0)$ & $4(15,3)$ & $11(45,8)$ & $3(13,0)$ \\
\hline Підвищена пітливість & $15(75,0)$ & $6(23,0)$ & $14(58,3)$ & $4(17,4)$ \\
\hline $\begin{array}{l}\text { Відчуття серцебиття, «завмирання», перебоїв } \\
\text { у роботі серця }\end{array}$ & $19(95,0)$ & $12(46,0)$ & $21(87,5)$ & $11(47,8)$ \\
\hline $\begin{array}{l}\text { Відчуття утруднення дихання («нестачі» } \\
\text { повітря, прискорене дихання) }\end{array}$ & $14(70,0)$ & $4(15,3)$ & $10(41,6)$ & $4(17,4)$ \\
\hline $\begin{array}{l}\text { Порушення функції органів травної системи } \\
\text { (схильність до діареї, запорів, метеоризм, біль) }\end{array}$ & $17(85,0)$ & $1(3,8)$ & $15(62,5)$ & $3(13,0)$ \\
\hline $\begin{array}{l}\text { Випадки втрати свідомості чи відчуття, що } \\
\text { можете знепритомніти }\end{array}$ & $3(15,0)$ & - & $2(8,3)$ & - \\
\hline $\begin{array}{l}\text { Головний біль (дифузний головний біль або } \\
\text { біль однієї половини голови, біль стискаючого } \\
\text { або пульсуючого характеру) }\end{array}$ & $20(100,0)$ & $11(42,3)$ & $22(91,6)$ & $4(17,4)$ \\
\hline $\begin{array}{l}\text { Зниження працездатності, швидка } \\
\text { втомлюваність }\end{array}$ & $20(100,0)$ & $3(11,5)$ & $20(83,3)$ & $1(4,3)$ \\
\hline $\begin{array}{l}\text { Порушення сну (труднощі засинання, } \\
\text { поверхневий сон, часті пробудження, } \\
\text { втомленість при пробудженні ранком) }\end{array}$ & $15(75,0)$ & $2(7,7)$ & $11(45,8)$ & $2(8,7)$ \\
\hline$M \pm m ; p$ & $\begin{array}{l}46,1 \pm 9,1 \\
P_{1}<0,001\end{array}$ & $11,4 \pm 3,1$ & $\begin{array}{l}34,8 \pm 4,6 \\
p_{2}<0,001\end{array}$ & $9,4 \pm 2,5$ \\
\hline
\end{tabular}

Примітка. $\mathrm{p}_{1}$ - порівняння з показниками 2-ї групи; $\mathrm{p}_{2}$ - порівняння з показниками 4-ї групи.

Висновки. Прояви вегетативної дисфункції у пацієнтів із хронічною хворобою нирок та цукровим діабетом 2-го типу відрізняються за структурою від проявів у хворих з хронічною хворобою нирок без цукрового діабету.

\section{ЛІТЕРАТУРА}

1. Bulletin of the World Health Organization. - 2018. No. 96. - P. 414-422D. DOI: http://dx.doi.org/10.2471/ BLT.17.206441

2. GBD 2015 Mortality and Causes of Death Collaborators. Global, regional, and national life expectancy, all-cause mortality, and cause-specific mortality for 249 causes of death, 1980-2015: a systematic analysis for the Global Burden of Disease Study 2015 / H. Wang, M. Naghavi, C. Allen [et al.] // Lancet. - 2016. - No. 388 (10053). - P. 1459-1544.

3. Worldwide access to treatment for end-stage kidney disease: a systematic review / T. Liyanage, T. Ninomiya, V. Jha [et al.] // Lancet. - 2015. - No. 385 (9981). - P. 1975-1982.

4. International Society of Nephrology's 0by25 initiative for acute kidney injury (zero preventable deaths by 2025): a human rights case for nephrology / R. L. Mehta,
Зі зростанням стадії хронічної хвороби нирок у пацієнтів з цукровим діабетом та без цукрового діабету відзначалося збільшення проявів вегетативної дисфункції, які не усуваються проведенням сеансів гемодіалізу.

J. Cerdá, E. A. Burdmann [et al.] // Lancet. - 2015. No. 385 (9987). - P. 2616-2643.

5. Prevalence of autonomic dysfunction among predialysis chronic kidney disease patients in a tertiary hospital, South East Nigeria / Obinna Onodugo, Ejikeme Arodiwe, Julius Okoye [et al.] // Afrю Health Sci. - 2018. No. 18 (4). - P. 950-957. DOI: 10.4314/ahs.v18i4.14

6. Cardiovascular risk and mortality in end-stage renal disease patients undergoing dialysis: sleep study, pulmonary function, respiratory mechanics, upper airway collapsibility, autonomic nervous activity, depression, anxiety, stress and quality of life: a prospective, double blind, randomized controlled clinical trial /Israel dos Reis Santos, Aline Roberta Danaga, Isabella de Carvalho Aguiar [et al.] // BMC Nephrol. 2013. - No. 14. - P. 215. DOI: 10.1186/1471-2369-14-215 
Огляди літератури, оригінальні дослідження, погляд на проблему, випадок з практики, короткі повідомлення

7. Autonomic regulation during quiet and active sleep states in very preterm neonates / S. Reulecke, S. Schulz, A. Voss// Front. Physiol. - 2012. - No. 3:61.10.3389/ fphys.2012.00061

\section{REFERENCES}

1. (2018). Bulletin of the World Health Organization, 96 414-422D. DOI: http://dx.doi.org/10.2471/BLT.17.206441

2. Wang, H., Naghavi, M., Allen, C., Barber, R.M., Bhutta, Z.A., \& Carter, A., et al. (2016). Mortality and Causes of Death Collaborators. Global, regional, and national life expectancy, all-cause mortality, and cause-specific mortality for 249 causes of death, 1980-2015: a systematic analysis for the Global Burden of Disease Study 2015. Lancet, 388 (10053), 1459-544.

3. Liyanage, T., Ninomiya, T., Jha, V., Neal, B., Patrice, H.M., \& Okpechi, I., et al. (2015). Worldwide access to treatment for end-stage kidney disease: a systematic review. Lancet, 385 (9981), 1975-1982.

4. Mehta, R.L., Cerdá, J., Burdmann, E.A., Tonelli, M., García-García, G., \& Jha, V., et al. (2015). International Society of Nephrology's 0by25 initiative for acute kidney injury (zero preventable deaths by 2025): a human rights case for nephrology. Lancet, 385 (9987), 2616-2643.

5. Obinna Onodugo, Ejikeme Arodiwe, Julius Okoye, Birinus Ezeala, Nkiru Onodugo, Ifeoma Ulasi, \& Chinwuba Ijoma (2018). Prevalence of autonomic dysfunction among
8. Вейн А. М. Вегетативные расстройства. Клиника, диагностика, лечение / А. М. Вейн. - М. : Медицина, 1998. -740 c. pre-dialysis chronic kidney disease patients in a tertiary hospital. South East Nigeria Afr. Health Sci., 18 (4), 950-957. DOI: 10.4314/ahs.v18i4.14

6. Israel dos Reis Santos, Aline Roberta Danaga, Isabella de Carvalho Aguiar, Ezequiel Fernandes Oliveira, Ismael Souza Dias, Jessica Julioti Urbano, \& Aline Almeida Martins, et.al. (2013). Cardiovascular risk and mortality in end-stage renal disease patients undergoing dialysis: sleep study, pulmonary function, respiratory mechanics, upper airway collapsibility, autonomic nervous activity, depression, anxiety, stress and quality of life: a prospective, double blind, randomized controlled clinical trial. BMC Nephrol., 14, 215. Published online 2013 Oct 8. DOI: $10.1186 / 1471-2369-14-215$

7. Reulecke, S., Schulz, S., \& Voss, A. (2012). Autonomic regulation during quiet and active sleep states in very preterm neonates. Front. Physiol., 3, 61. 10.3389/ fphys.2012.00061

8. Vein, A.M. (Ed.). (1998). Vegetativnye rasstroystva. Klinika, diagnostika, lechenie [Autonomic disorders. Clinic, diagnosis, treatment]. Moscow: Meditsina [in Russian]

\title{
ОСОБЕННОСТИ ТЕЧЕНИЯ ВЕГЕТАТИВНЫХ НАРУШЕНИЙ У БОЛЬНЫХ, НАХОДЯЩИХСЯ НА ПРОГРАММНОМ ГЕМОДИАЛИЗЕ, С УЧЕТОМ НАЛИЧИЯ У НИХ САХАРНОГО ДИАБЕТА 2-ГО ТИПА
}

ОС. Т. Рустамян, И. П. Катеренчук

\author{
Украинская медицинская стоматологическая академия, Полтава
}

РЕЗЮМЕ. Цель - провести сравнительный анализ клинических проявлений вегетативных нарушений у больных, находящихся на программном гемодиализе, с учетом наличия у них сахарного диабета 2-го типа.

Материал и методы. В исследование привлечено 93 больных, лечившихся в 2019 году в центре нефрологии и диализа г. Полтава. В зависимости от стадии заболевания выделены две группы больных - 44 6ольных (47,3 \%), находящихся на программном гемодиализе (исследовательская группа - ИГ) и 49 больных (52,7%) с ХБП І-ІІ стадии (контрольная группа - КГ), в каждой из которых больные были стратифицированы на две подгруппы: с наличием сахарного диабета 2-го типа (СД) и без СД: ИГ 20 и 24 пациента, КГ 26 и 23 соответственно. Для выявления признаков вегетативных нарушений использовали опросник А. М. Вейна. Вегетативную дисфункцию диагностировали, когда суммарный балл превышал число 15. Статистический анализ проводили с помощью программного обеспечения Microsoft Excel, применяя варианты статистического вычисления (среднее отклонение, среднее арифметическое, стандартную погрешность). Достоверность различий между сравнительными группами определяли с помощью параметрического критерия Стьюдента.

Результаты. По результатам анкетирования пациентов по стандартизированному опроснику А. М. Вейна было установлено, что у больных, находящихся на программном гемодиализе с СД в совокупности ответов больных признаки вегетативных расстройств оценивались $(46,1 \pm 9,1)$ балла при минимально-максимальных значениях (19-58), тогда как в контрольной группе с СД $(11,4 \pm 3,1)$ балла, при минимально-максимальных значениях (7-18), p<0,001. Такое же значение получено и при сравнении ИГ без СД $(34,8 \pm 4,6)$ балла, при минимально максимальных значениях (17-43) и КГ без СД $(9,4 \pm 2,5)$ балла, при минимально максимальных значениях $(7-15)$, p<0,001. Частота возникновения вегетативной дисфункции у ИГ с СД и ИГ без СД не имела статистически значимой разницы (р>0,05), но сама вегетативная дисфункция в группах отличалась по структуре.

Выводы. Проявления вегетативной дисфункции у пациентов с хронической болезнью почек с сахарным диабетом 2-го типа отличаются по структуре от проявлений у больных с хронической болезнью почек без сахарного 
Огляди літератури, оригінальні дослідження, погляд на проблему, випадок з практики, короткі повідомлення диабета. С ростом стадии хронической болезни почек у пациентов с сахарным диабетом и без сахарного диабета отмечалось увеличение проявлений вегетативной дисфункции, которые не устраняются проведением сеансов гемодиализа.

КЛЮчЕВЫЕ СЛОВА: гемодиализ; почечная недостаточность; вегетативные расстройства.

\title{
PECULIARITIES OF THE COURSE OF VEGETATIVE DISORDERS IN PATIENTS WHO ARE ON PROGRAM HEMODIALYSIS, TAKING INTO ACCOUNT THE PRESENCE OF TYPE 2 DIABETES
}

\author{
@S. T. Rustamian, I. P. Katerenchuk \\ Ukrainian Medical Stomatological Academy, Poltava
}

\begin{abstract}
SUMMARY. The aim - to conduct a comparative analysis of clinical manifestations of autonomic disorders in patients undergoing programmed hemodialysis, taking into account the presence of type 2 diabetes mellitus.

Material and Methods. The study involved 93 patients who were treated in 2019 at the Center for Nephrology and Dialysis, Poltava. Depending on the stage of CKD, two groups of patients were identified - 44 patients (47.3\%) on program hemodialysis (experimental group - EG) and 49 patients (52.7 \%) with CKD stage I-II (control group - CG), in each of which patients were stratified into two subgroups: with the presence of type 2 diabetes mellitus (DM) and without diabetes: EG 20 and 24 patients, CG 26 and 23, respectively. A questionnaire AM Wayne was used to identify signs of autonomic disorders. Autonomic dysfunction occurred when the total score exceeded 15. Statistical analysis was performed using Microsoft Excel software, using statistical calculation options (standard deviation, arithmetic mean, standard error). The probability of differences between the comparison groups was determined using the parametric Student's test.

Results and Discussion. According to the results of questionnaires of patients according to the standardized questionnaire A.M. Wayne found that in patients on program hemodialysis with diabetes in the set of responses of patients signs of autonomic disorders were evaluated (46.1 \pm 9.1$)$ points at minimum-maximum values (19-58), then as in the control group with diabetes $(11.4 \pm 3.1)$ points, at the minimum-maximum values $(7-18), p<0.001$. The same value was obtained when comparing EG without diabetes (34.8 \pm 4.6$)$ points, at the minimum-maximum values (17-43) and CG without diabetes $(9.4 \pm 2.5)$ points, at the minimum-maximum values $(7-15), p<0.001$. The incidence of autonomic dysfunction in EG with diabetes and EG without diabetes did not have a statistically significant difference $(p>0.05)$, but the autonomic dysfunction in the groups differed in structure.

Conclusions. Manifestations of autonomic dysfunction in patients with chronic kidney disease with type 2 diabetes differ in structure from the manifestations in patients with chronic kidney disease without diabetes. With the increase in the stage of chronic kidney disease in patients with diabetes and without diabetes, there was an increase in the manifestations of autonomic dysfunction, which are not eliminated by hemodialysis sessions.
\end{abstract}

KEY WORDS: hemodialysis; renal failure; autonomic disorders. 